Chirurgia (2019) 114: 704-710

No. 6, November - December

Copyright $\odot$ Celsius

http://dx.doi.org/10.21614/chirurgia.114.6.704

\title{
The Effect of Bariatric Surgery on Premalignant Endometrial Pathology in Morbidly Obese Patients
}

\author{
Irina Balescu ${ }^{1}$, Nicolae Bacalbasaa ${ }^{2,3}$, Catalin Copaescu ${ }^{1,4}$ \\ 'Ponderas Academic Hospital Bucharest, Romania \\ 2"Carol Davila" University of Medicine and Pharmacy, Bucharest, Romania \\ 3"Center of Excellence in Translational Medicine, Fundeni Clinical Institute, Bucharest, Romania \\ "'Grigore T Popa" University of Medicine and Pharmacy, Iasi, Romania
}

Corresponding author: Catalin Copaescu, MD PhD Associated Professor of Surgery Ponderas Academic Hospital Nicolae Caramfil Street, no. 85 A district 1, Bucharest, Romania E-mail: catalin.copaescu@ponderas-ah.ro

\section{Rezumat}

Efectul chirurgiei bariatrice asupra modificărilor endometriale premaligne la pacientele cu obezitate morbidă

Scop: De a investiga efectul chirurgiei bariatrice asupra patologiei endometriale premaligne la pacientele cu obezitate morbidă aflate în postmenopauză.

Material şi Metodă: În perioada 2014-2019, în "Ponderas" Academic Hospital şase paciente cu obezitate morbidă şi leziuni endometriale premaligne aflate în postmenopauză au fost supuse intervenției de chirurgie bariatrică de tipul sleeve-ului gastric.

Rezultate: La momentul intervenției de chirurgie bariatrică valoarea medie a indicelui de masă corporală (IMC) a fost de 43,5 $\mathrm{kg} / \mathrm{m}^{2}$ (între $41,5 \mathrm{~kg} / \mathrm{m}^{2}$ şi $48,5 \mathrm{~kg} / \mathrm{m}^{2}$ ) în timp ce valoarea medie a vârstei a fost de 61 ani (între 58 şi 63 ani). Biopsia preoperatorie a mucoasei endometriale a demonstrat prezența hiperplaziei endometriale simple în cinci cazuri şi respectiv a hiperplaziei endometriale complexe într-un caz, în timp ce grosimea medie a mucoasei endometriale la rezonanța magnetică nucleară (RMN) a fost de 2,1 cm (între 1,5 şi $2,8 \mathrm{~cm}$ ). La un an după intervenția de chirurgie bariatrică, IMC-ul mediu a scăzut la $26.5 \mathrm{~kg} / \mathrm{m}^{2}$ (între $=24 \mathrm{~kg} / \mathrm{m}^{2}$ $28 \mathrm{~kg} / \mathrm{m}^{2}$ iar grosimea medie a endometrului determinată la RMN a scăzut la $0,8 \mathrm{~cm}$ (între $0,5 \mathrm{~cm}$ şi $1,1 \mathrm{~cm}$ ). Biopsia a demonstrat prezența endometrului de aspect normal în patru cazuri şi respectiv a hiperplaziei simple în două cazuri.

Concluzii: Chirurgia bariatrică pare să aibă un efect important asupra patologiei endometriale premaligne. Prin urmare se pare că chirurgia bariatrică şi scăderea ponderală pe care aceasta o induce 
ar putea scădea riscul de transformare malignă endometrială la pacientele cu obezitate morbidă aflate în postmenopauză.

Cuvinte cheie: chirurgie bariatrică, obezitate morbidă, patologie premalignă endometrială

\begin{abstract}
Aim: To investigate the effect of bariatric surgery on premalignant endometrial pathology in postmenopausal morbidly obese patients.

Material and Methods: Between 2014 and 2019, in "Ponderas" Academic Hospital six postmenopausal morbidly obese patients with premalignant endometrial pathology were submitted to bariatric surgery consisting of sleeve gastrectomy.

Results: At the time of bariatric surgery, the mean body mass index (BMI) value was of $43.5 \mathrm{~kg} / \mathrm{m}^{2}$ (range $=41.5 \mathrm{~kg} / \mathrm{m}^{2}-48.5 \mathrm{~kg} / \mathrm{m}^{2}$ ) while the mean age was of 61 years (range $=58-63$ years). The preoperative biopsy of the endometrial lining demonstrated the presence of simple endometrial hyperplasia in five cases and complex endometrial hyperplasia in one case while the mean thickness of the endometrial lining at magnetic resonance imaging (MRI) was of $2.1 \mathrm{~cm}$ (range $=1.5-2.8$ $\mathrm{cm}$ ). At one year follow-up, the mean BMI was of $26.5 \mathrm{~kg} / \mathrm{m}^{2}$ (range $=24 \mathrm{~kg} / \mathrm{m}^{2}-28 \mathrm{~kg} / \mathrm{m}^{2}$ ) while the mean thickness estimated at MRI was of $0.8 \mathrm{~cm}$ (range $=0.5-1.1 \mathrm{~cm}$ ). The biopsy demonstrated the presence of normal endometrium in four cases and simple hyperplasia in two cases.

Conclusions: Bariatric surgery seems to have an important effect on premalignant endometrial conditions. Therefore, bariatric surgery and consecutive weight loss might decrease the risk of malignant transformation in postmenopausal morbidly obese women.
\end{abstract}

Key words: bariatric surgery, morbid obesity, premalignant endometrial condition

\section{Introduction}

In the last decade obesity has become a serious health problem affecting both adults and children worldwide; in the meantime hormonal, metabolic and inflammatory modifications induced by obesity lead to the development of multiple comorbidities such as diabetes mellitus, atherosclerosis, sleep apnea and arterial hypertension (1). Moreover, in the last years attention was focused on identifying the potential connection or relationship between cancer genesis and obesity (2). In this respect, a proportional correlation between BMI values and the risk of cancer development has been described by certain authors, the strongest correlations being suspected for endometrial, breast, colon and prostate cancer. A prospective, pilot study conducted by Argenta and published in 2013 demonstrated that $7 \%$ of women presenting for bariatric surgery associated endometrial premalignant pathologies (3); moreover, another study conducted on the theme of the influence of bariatric surgery on cancer development underlined the fact that after bariatric surgery cancer development risk decreased from $5.8 \%$ to $3.5 \%(p=0.01)(2)$. The largest study which investigated the efficacy of bariatric surgery in preventing the risk of cancer development comes from a Swedish group which prospectively compared the outcomes of patients submitted to bariatric surgery on a ten year period to the ones reported in a control group and demonstrated a significant reduction of cancer risk after bariatric surgery $\left(p=0.0001, H R=0.58,0.44^{-}\right.$ $0.77)$ (4). In a more recent study conducted by the same Swedish group the authors came to demonstrate that this protective effect is 
significantly higher in women when compared to men; when it comes to the different types of malignancies, the authors underlined the fact that this protective effect was most clearly demonstrated for endometrial cancer (5).

The aim of the present study is to investigate the effect of bariatric surgery on premalignant endometrial pathology.

\section{Material and Method}

After obtaining the approval of the Ethical Committee all postmenopausal morbidly obese women who presented in our hospital for bariatric surgery were also investigated for the association of premalignant endometrial conditions; all patients were informed and were introduced in the present study after obtaining their written consent.

The study was a prospective one, inclusion criteria being represented by candidates for bariatric surgery of female sex, having a BMI $>40 \mathrm{~kg} / \mathrm{m}^{2}$, documented postmenopausal status and endometrial lining of at least $0.5 \mathrm{~cm}$. Exclusion criteria were represented by the presence of at least one episode of vaginal bleeding since the menopausal onset as well as a personal history of endometrial cancer or known endometrial hyperplasia. In the meantime, patients with previous history of breast cancer and Tamoxifen use as well as those with recent history of other hormone replacement (excluding progesterone) were also excluded. Preoperatively, all candidates for bariatric surgery were submitted to a complete preoperative work up which is routinely used for bariatric surgery candidates and which included abdominal ultrasound. Among these cases there were 34 postmenopausal morbidly obese women in whom endometrial thickness was suspected therefore, they were submitted to transvaginal ultrasound and pelvic magnetic resonance; however, among these cases endometrial thickening was confirmed in six cases (Fig. 1-3). Therefore, in these cases endometrial biopsy was performed and the patients were informed in regard to the results of their endometrial biopsies. After excluding the association of endometrial cancer all six

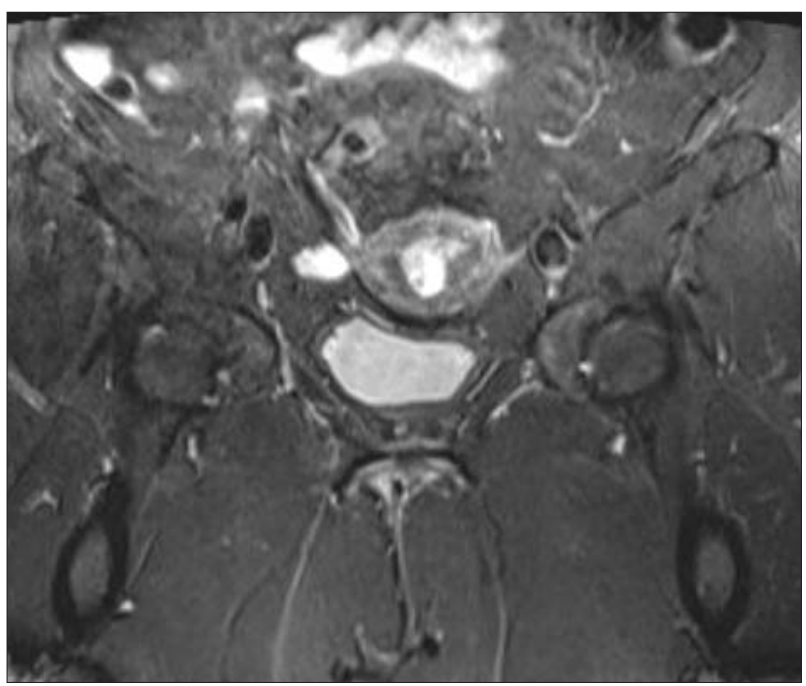

Figure 1. Preoperative MRI demonstrating the presence of diffuse thickening of the endometrial mucosa - in a patient with preoperative $\mathrm{BMI}=43 \mathrm{~kg} / \mathrm{m}^{2}$

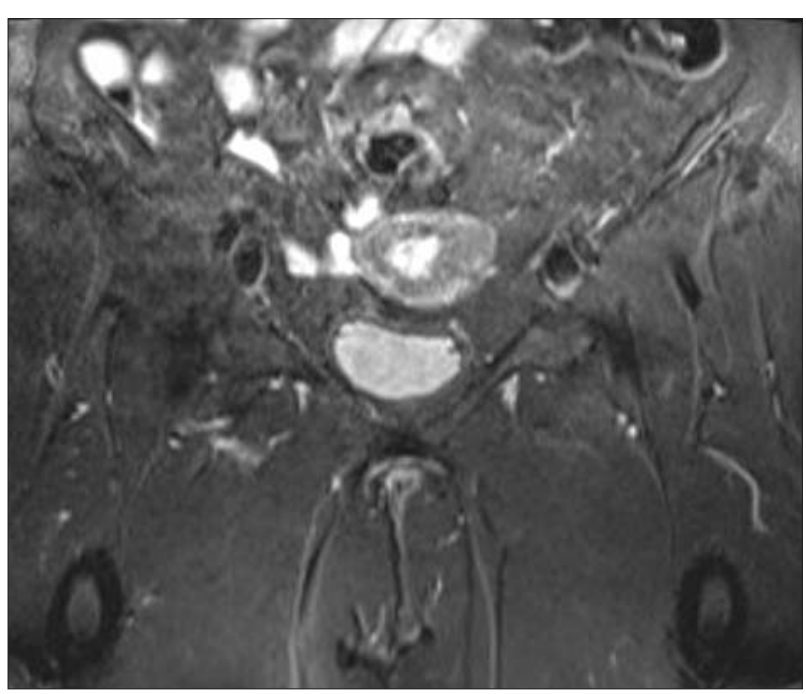

Figure 2. Preoperative MRI demonstrating the presence of diffuse thickening of the endometrial mucosa - in a patient with preoperative $\mathrm{BMI}=42 \mathrm{~kg} / \mathrm{m}^{2}$

patients were submitted to bariatric surgery, sleeve gastrectomy being performed. As for the surgical technique for sleeve gastrectomy, the standard approach was performed in all cases; all patients were placed in a French position under general anesthesia. The surgical procedure consisted of greater curvature dissection using a vessel sealing device followed by gastric resection from $1 \mathrm{~cm}$ to the pylorus to the angle of His using mechanical linear stapling device and a 35-fr calibration bougie. In all cases the 


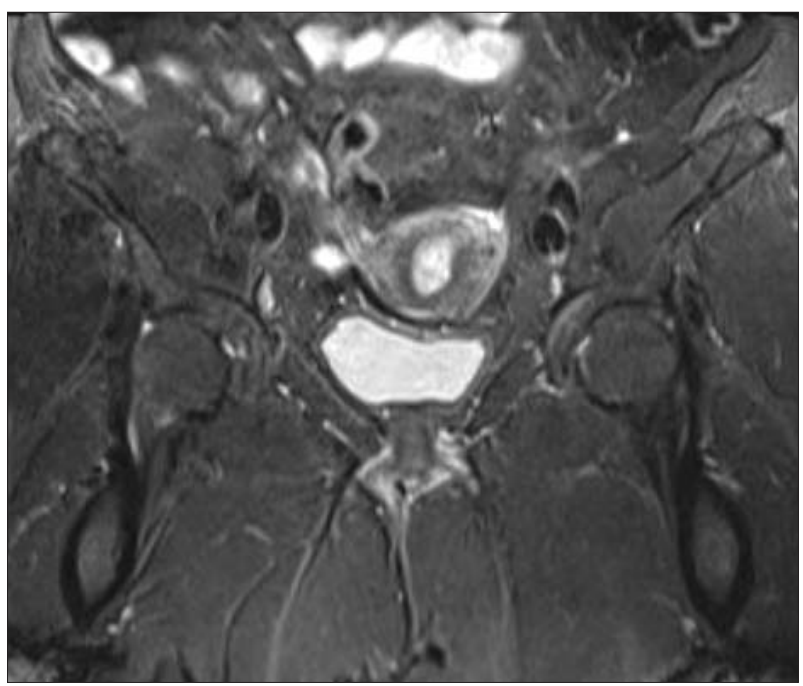

Figure 3. Preoperative MRI demonstrating the presence of diffuse thickening of the endometrial mucosa - in a patient with preoperative $\mathrm{BMI}=44 \mathrm{~kg} / \mathrm{m}^{2}$

stapled line was over sewn using a 3.0 polypropylene running suture. In the meantime metallic clips were placed at the proximal and distal extremity of the running suture in order to have a radiological visible mark. A naso-gastric tube as well as a drainage tube were left in place for the next 24 hours $(6,7)$.

At one year follow up all patients were submitted to a complete checkup including vaginal ultrasound and endometrial biopsy.

\section{Results}

All six patients were submitted to bariatric surgery consisting of sleeve gastrectomy between 2014 and 2019 in "Ponderas" Academic Hospital. The mean age of the six patients at the time of bariatric surgery was of 61 years (range $=58-63$ years) while the mean BMI value was of $43.5 \mathrm{~kg} / \mathrm{m}^{2}\left(\right.$ range $\left.=41.5 \mathrm{~kg} / \mathrm{m}^{2}-48.5 \mathrm{~kg} / \mathrm{m}^{2}\right)$. Other associated comorbidities were represented by arterial hypertension in four cases, diabetes mellitus in three cases, dyslipidemia in five cases and sleep apnea in two cases. All cases diagnosed with type II diabetes mellitus associated preoperative oral antidiabetic treatment, with a mean value of the glycated hemoglobin of $6,3 \mathrm{~g} / \mathrm{dl}($ range $=5.6-7.4 \mathrm{~g} / \mathrm{dl})$ and a mean value of $\mathrm{C}$ peptide of $3.4 \mathrm{ng} / \mathrm{ml}$ (range $=3.1 \mathrm{ng} / \mathrm{ml}-3.7 \mathrm{ng} / \mathrm{ml}$ ).
The vaginal ultrasound revealed the presence of a mean endometrial lining thickness of $1.8 \mathrm{~cm}$ (range $=1.3-2.9 \mathrm{~cm}$ ) while at MRI the mean thickness of the endometrial lining was of $2.1 \mathrm{~cm}$ (range $=1.5-2.8 \mathrm{~cm}$ ). In all cases hysteroscopy and endometrial biopsy was performed revealing the presence of simple hyperplasia in five cases and complex hyperplasia without atypia in one case. After excluding the association of endometrial malignancies, all the six patients were submitted to bariatric surgery and sleeve gastrectomy being performed with no perioperative or postoperative complications. The mean length of surgery was 75 minutes (range $=60-100$ minutes) while the mean blood loss was of 125 $\mathrm{ml}$ (range $=50-200 \mathrm{ml}$ ). All patients were discharged at $48-72$ hours postoperatively and were asked to maintain liquid diet for the next 10 days. At one year follow up the mean BMI was of $26.5 \mathrm{~kg} / \mathrm{m}^{2}$ (range $=24 \mathrm{~kg} / \mathrm{m}^{2}-28$ $\mathrm{kg} / \mathrm{m}^{2}$ ) while the mean thickness of the endometrial lining estimated at MRI was of $0.8 \mathrm{~cm}$ (range $=0.5-1.1 \mathrm{~cm}$ ). The biopsy demonstrated the presence of normal endometrium in four cases and simple hyperplasia in two cases. However, one of the two patients with persistant simple hyperplasia presented the resolution of the histopathological modification at 18 months follow-up. The evidence of the significant improvement offered by the trans-vaginal ultrasound and endometrial biopsy supported no indication for pelvic MRI.

Due to the evident improvement at the vaginal ultrasound which was also confirmed by biopsy we decided not to re-schedule the patients to pelvic MRI.

In the meantime the other comorbidities were partially or completely controlled at this time; therefore, arterial hypertension was still present in one case while dyslipidemia was present in another case; however, the necessity of antihypertensives as well as of statin reported a significant decrease. As for sleep apnea and diabetes, none of these comorbidities was still present at one year follow up. 


\section{Discussions}

Endometrial cancer still represents a significant health problem affecting women worldwide being the fourth most commonly encountered malignancy after breast, lung and colorectal cancer. Moreover, although most patients are diagnosed in early stages of the disease and trend to have a favorable prognostic, in certain cases the diagnostic is established in advanced stages of the disease and the overall outcome is extremely poor. Recent epidemiological studies came to demonstrate that endometrial cancer related death trends to increase in the last decades despite recent advantages in terms of therapeutic strategies for endometrial cancer patients. This aspect can be explained by multiple mechanisms, one of the most significant ones being represented by the alarming increase of the incidence of obesity especially in postmenopausal women (8-11). This correlation has been clearly demonstrated so far especially for type I endometrial cancer, a histopathological subtype which is well known to be an estrogen-dependent one; moreover, recent studies have demonstrated that such patients have significantly higher rates of other obesity driven health problems related death when compared to cases without endometrial cancer (11).

As for the pathogenic mechanisms which are responsible for endometrial cancer development in obese women it seems that obesity driven chronic inflammatory status as well as a higher amount of unopposed estrogen play a principal role $(11,12)$. Therefore, it is well known the fact that endometrial cell proliferation is strongly influenced by the circulating levels of estrogens, which are found in significantly higher concentrations in morbidly obese women due to a higher amount of adipose tissue which will convert androstenedione to estrone and will aromatize the androgens to estradiol; in consequence higher amounts of circulating estrogens (unopposed by progesterone which becomes in this way insufficient) will stimulate endometrial lining proliferation and will induce the apparition of premalignant endometrial conditions. This mechanism is best demonstrated by the Postmenopausal Estrogen/Progestin Intervention Trial which reported a $62 \%$ rate of endometrial hyperplasia over a period of three years (13). Interestingly, this pathogenic mechanism is responsible especially for the development of type I endometrial cancer (also known as endometroid endometrial cancer), this aspect being in fact a possible explanation for the association between type I endometrial cancer and obesity (14).

In the meantime, obesity is associated with the development of chronic insulin resistance, translated initially into higher levels of circulating insulin which will act as a growth factor stimulating both the ovaries and the adrenal glands; in consequence, higher levels of circulating estrogens are to be expected in such cases. In this context, another frequent finding is the one of increased levels of insulin growth factor which plays a central role in cellular proliferation and neoplastic transformation, endometrial cells exhibiting high levels of insulin growth factor receptors (1517). Other incriminated factors are represented by inflammatory markers such as adiponectine and leptine which present important modifications of their circulating levels in obese patients and which seem to be involved in the process of endometrial proliferation and premalignant and even malignant transformation (18-20).

When it comes to the connection between endometrial hyperplasia and endometrial cancer risk, it should be underlined the fact that all types of endometrial hyperplasia present at a certain moment of their evolution the risk of malignant transformation due to the apparition of nuclear atypia. However, this risk is strongly influenced by the type of the hiperplastic lesion, simple hyperplasia presenting a further risk of malignization of $1 \%$, significantly lower when compared to complex hyperplasia (in which the risk reaches 28\%) (21). More recent studies have demonstrated that in fact this malignant transformation is a continuous process, 
progressing from simple hyperplasia to com- $^{-}$ plex hyperplasia and endometrial atypia (3).

In such cases multiple therapeutic strategies have been proposed, beginning from exogenous administration of progesterone in order to oppose to the higher amounts of circulating estrogens to the administration of other schemes of endocrine therapies or to the creation of personalized programs of weight loss. However endocrine therapies proved to be not so effective as expected due to the induction of supplementary weight gain while personalized programs of weight loss proved not to induce a durable process of weight loss.

In the meantime bariatric surgery proved to be extremely efficient in order to induce a rapid and durable weight loss as well as an efficient control of the associated comorbidities such as diabetes and arterial diseases by reducing the insulin resistance, the circulatory levels of the inflammatory markers and of the insulin growth factors; therefore, all factors which were considered as responsible for endometrial cancer development seemed to be modulated after bariatric surgery (22-24). Beginning from this information, the hypothesis of the potential protective role of bariatric surgery against endometrial cancer genesis has been proposed and was tested in few prospective studies $(3-5,25)$. One of the largest such studies was published in 2013 and included 59 morbidly obese patients diagnosed with premalignant endometrial conditions submitted to gastric bypass at the Department of Obstetrics and Gynecology from the University of Minnesota, Minneapolis, United States of America; at one year follow-up all but three patients still presented simple hyperplasia while no patient presented the progression of the lesions to dysplasia or cancer (3).

Moreover, bariatric surgery as a therapeutic strategy in morbidly obese patients with premalignant endometrial lesions has been also introduced in February 2016 in the guidelines of The Royal College of Obstetricians and Gynaecologists (RCOG) and the British Society for Gynaecological Endoscopy (BSGE). According to this guideline, the affirmation that bariatric surgery may reduce the risk of malignant endometrial transformation has been considered to have a level 2 of evidence (26).

The strength of the study consists of demonstrating the efficacy in inducing reversibility of the endometrial premalignant changes of the endometrium induced by obesity after bariatric surgery. Moreover, this reversibility was proven by performing an endometrial biopsy which clearly demonstrated the presence of premalignant lesions at the time of entering the study as well as the regression of the lesions once weight loss process took place. However, our study also has two important limitations: the first one is related to the small number of cases introduced in the current paper, which can not provide us the opportunity to draw some definitive conclusions. Another limitation of the study is represented by the fact that although the postoperative endometrial modifications were clearly demonstrated by the histopathological and US studies, the pelvic MRI is missing.

\section{Conclusions}

Bariatric surgery seems to have a protective role against the risk of endometrial cancer in postmenopausal women by inducing regression of the premalignant modifications at this level; therefore, in a significant number of cases presenting premalignant conditions in association with morbid obesity bariatric surgery might induce their reversibility. The explanation of this process is related to the modification of hormonal and inflammatory status. However larger prospective studies are still needed in order to establish which cases might benefit most from this therapeutic strategy.

\section{Conflict of Interest}

The authors declare no conflicts of interests.

\section{References}

1. Modesitt S, Walker J. Obesity crisis in cancer care: gynecologic cancer prevention, treatment, and survivorship in obese women in the United States. Gynecol Oncol. 2014;133:1-3. 
2. McCawley GM, Ferriss JS, Geffel D, Northup CJ, Modesitt SC Cancer in obese women: potential protective impact of bariatric surgery. J Am Coll Surg. 2009;208:1093-8.

3. Argenta PA, Kassing M, Truskinovsky AM, Svendsen CA. Bariatric surgery and endometrial pathology in asymptomatic morbidly obese women: a prospective, pilot study. BJOG. 2013;120:795-800

4. Sjostrom L, Gummesson A, Sjostrom CD, Narbro K, Peltonen M, Wede $\mathrm{H}$, et al. Effects of bariatric surgery on cancer incidence in obese patients in Sweden (Swedish Obese Subjects Study): a prospective, controlled intervention trial. Lancet Oncol. 2009; 10:653-62.

5. Anveden A, Taube M, Peltonen M, Jacobson P, AnderssonAssarsson JC, Sjoholm K, et al. Long-term incidence of femalespecific cancer after bariatric surgery or usual care in the Swedish Obese Subjects Study. Gynecol Oncol. 2017;145:224-9.

6. Copaescu C. Laparoscopic sleeve gastrectomy for morbid obesity. Chirurgia (Bucur). 2006;104:79-85.

7. Turcu F, Balahura C, Doras I, Constantin A, Copaescu C. Symptomatic Stenosis after Laparoscopic Sleeve Gastrectomy Incidence and Management in a High-Volume Bariatric Surgery Center. Chirurgia (Bucur). 2018;113: 826-36.

8. Jemal A, Siegel R, Ward E, Hao Y, Xu J, Murray T, et al. Cancer statistics, 2008. CA Cancer J Clin. 2008;58:71-96.

9. Rose SL, Bradley SL, Lutgendorf SK, Sorosky J, Anderson B. The impact of adjuvant radiation therapy on long-term quality of life in patients with stage I endometrial cancer. Gynecol Oncol 2004; 92:479-80.

10. von Gruenigen VE, Gil KM, Frasure HE, Jenison EL, Hopkins MP. The impact of obesity and age on quality of life in gynecologic surgery. Am J Obstet Gynecol. 2005;193:1369-75.

11. Fader AN, Arriba LN, Frasure HE, von Gruenigen VE. Endometria cancer and obesity: epidemiology, biomarkers, prevention and survivorship. Gynecol Oncol. 2009;114:121-7.

12. Schouten LJ, Goldbohm RA, van den Brandt PA. Anthropometry, physical activity, and endometrial cancer risk: results from the Netherlands Cohort Study. J Natl Cancer Inst. 2004;96:1635-8.

13. Effects of hormone replacement therapy on endometrial histology in postmenopausal women. The Postmenopausal Estrogen/ Progestin Interventions (PEPI) Trial. The Writing Group for the PEPI Trial. JAMA. 1996;275:370-5

14. Grandi G, Perrone AM, Chiossi G, Friso S, Toss A, Sammarini M, et al. Increasing BMI is associated with both endometrioid and serous histotypes among endometrial rather than ovarian cancers: a case- to-case study. Gynecol Oncol. 2019;154:163-8.

15. O'Mara BA, Byers T, Schoenfeld E. Diabetes mellitus and cancer risk: a multisite case-control study. J Chronic Dis. 1985;38:435-41.

16. Adami HO, McLaughlin J, Ekbom A, Berne C, Silverman D, Hacker $D$, et al. Cancer risk in patients with diabetes mellitus. Cancer Causes Control. 1991;2:307-14.

17. Talavera F, Reynolds RK, Roberts JA, Menon KM. Insulin-like growth factor I receptors in normal and neoplastic human endometrium. Cancer Res. 1990;50:3019-24.

18. Cust AE, Kaaks R, Friedenreich C, Bonnet F, Laville M, Tjonneland A, et al. Metabolic syndrome, plasma lipid, lipoprotein and glucose levels, and endometrial cancer risk in the European Prospective Investigation into Cancer and Nutrition (EPIC). Endocr Relat Cancer. 2007;14:755-67.

19. Sharma D, Saxena NK, Vertino PM, Anania FA. Leptin promotes the proliferative response and invasiveness in human endometrial cancer cells by activating multiple signal-transduction pathways. Endocr Relat Cancer. 2006;13:629-40.

20. Cymbaluk A, Chudecka-Glaz A, Rzepka-Gorska I. Leptin levels in serum depending on Body Mass Index in patients with endometrial hyperplasia and cancer. Eur J Obstet Gynecol Reprod Biol 2008; 136:74-7.

21. Kurman RJ, Kaminski PF, Norris HJ. The behavior of endometrial hyperplasia. A long-term study of "untreated" hyperplasia in 170 patients. Cancer. 1985;56:403-12.

22. Perugini RA, Malkani S. Remission of type 2 diabetes mellitus following bariatric surgery: review of mechanisms and presentation of the concept of 'reversibility'. Curr Opin Endocrinol Diabetes Obes. 2011;18:119-28.

23. Woelnerhanssen $B$, Peterli R, Steinert RE, Peters $T$, Borbely $Y$, Beglinger C. Effects of postbariatric surgery weight loss on adipokines and metabolic parameters: comparison of laparoscopic Roux-en-Y gastric bypass and laparoscopic sleeve gastrectomy-a prospective randomized trial. Surg Obes Relat Dis. 2011;7: 561-8.

24. Gosman GG, Katcher HI, Legro RS. Obesity and the role of gut and adipose hormones in female reproduction. Hum Reprod Update. 2006;12:585-601.

25. Mackintosh ML, Crosbie EJ. Obesity-driven endometrial cancer: is weight loss the answer? BJOG. 2013;120:791-4.

26. RCOG/BSGE Green-top Guideline No. 67 Royal College of Obstetricians and Gynaecologists 2016. 